\title{
AN EMPIRICAL INVESTIGATION OF THE UTILIZATION OF EXTERNAL AND INTERNAL BOARD OF DIRECTORS AND MANAGEMENT ADVISORY ASSISTANCE ON THE Performance of SMall Business
}

\author{
Diane J. Garsombke \\ University of Wisconsin Superior \\ Thomas W. Garsombke \\ University of Minnesota Crookston
}

\begin{abstract}
This article reports the usage and effectiveness of advisory bodies (i.e. advisory boards, boards of directors, management consultants, accountants, family, friends) that exist in smaller businesses. The authors find that advisory boards have the most significant impact on various company performance criteria. This result implies that strategic marketing and planning is enhanced by the use of advisory boards. Additionally, the authors discover that the entrepreneur's attitude is even more important than previously reserched inhibitors of lack of resources to greater use of advisors.
\end{abstract}

\section{Introduction}

The United States has a long tradition of entrepreneurship in small and medium sized businesses. Unfortunately, new startup firms are subject to many perils in the business world. With a $60 \%$ failure rate cited for new endeavors, it is important that entrepreneurs learn how to overcome the obstacles to success. From the past research on business failures, many firms suffer due to inadequate knowledge by the owner/manager on running the business - poor understanding of markets, the customer and competition, inadequate financial controls, lack of strategic planning, and inadequate capitalization. Gobeli and Seville $(1989,8)$ state that "lack of management expertise is the primary cause of small business failure."

Researchers have assessed the reasons for success and failure in small business. Dimma (1996) and Montagno et al. (1986) emphasize the importance of strategic planning to entrepreneurs who concentrate only on day-to-day operations. The primary reason for business failures is the lack of marketing and managerial expertise (Fox, 1983; Miskin and Rose, 1990). Khan and Rocha (1982), however, cite four interrelated problems in marketing, accounting, inventory and cash flow which endanger the small firm's ability to survive and 
prosper. Ibrahim and Goodwin (1986) conclude that entrepreneurial behavior and managerial skills are key success factors for new startups.

Entrepreneurs often lack the skills and experience necessary to overcome many problems encountered. To compensate for their lack of knowledge, entrepreneurs seek expertise from persons and groups both internal and external to the firm. Aid can be formal or informal. For instance, some executives set up a board of directors. Boards can be of two types 1) advisory - members give their opinions to the owner/manager but are not held legally or structurally to the firm or 2) governing - members make decisions on resource allocations as part of the legal structure of the firm. Others turn to personal contacts such as friends, family, and marketing, advertising, and management consultants on an ad-hoc basis. The government or trade association may offer valuable assistance to the small business executive as well. The question to be addressed by this research is: To what degree does the use of an advisory or governing board of directors or management advisory assistance impact on the successful performance of the firm?

The entrepreneur is ultimately the person to whom the blame is placed when the firm fails. Is it in the best interest of the firm for the owner/manager to turn to different advisory persons or groups? Do the practices of asking for assistance follow a pattern for more successful firms? This information could help entrepreneurs to learn which types of assistance are most beneficial. Given the limited time and financial resources available to most entrepreneurs, this research may pinpoint the critical situations and resources where getting assistance "pays off."

This study will provide information on the use of a board of directors and other advisors and the linkage to performance measures which are key to strategic marketing and planning. A second area of investigation is to determine the major inhibitors which prevent small businesses from establishing and using board of directors/advisory assistance.

\section{Previous Research}

\section{Assistance Forms}

Most research which has been done on the topic of boards of directors and managerial advisory assistance in the United States focuses on the structure, composition, recruitment, forms and sources of assistance (Baldwin and Hughes, 1995; Baysinger and Hoskisson, 1990; Business Owner, 1990; Kesner, 1989; Lorsch, 1995). Fox's (1984) research, for example, focuses in on the types and structures of small business boards of directors. He states that a panel of counselors can help small business owners in the areas of marketing, managerial and technological advice. His work has shown that "quasi-boards" (non-governing and advisory only) can offer ideas and recommendations to help strengthen the business by formal planning, deliberation in major decision making and providing outside objectivity. The study by Nelson (1989) 
confirms that female entrepreneurs value outside assistance in two areas: basic business support and for day-to-day business support in planning, operating and coordinating. In their interviews of 148 small businesses in Oregon, Gobeli and Seville (1989) found that 79\% of the firms used CPA firms for accounting services. In determining the sources of assistance, Baldwin and Hughes's (1995) book paralleled the research of Franklin and Goodwin (1986). Both writings found that small businesses overwhelmingly turned to accountants, lawyers and bankers for most of their managerial problems.

\section{Perceived Effectiveness of Assistance}

The primary focus of past research has been on the entrepreneur's perceived effectiveness of the assistance type or form, as measured by an effectiveness scale. Professional consultants and advisors, such as accountants, bankers, and lawyers have been rated "high" in their effectiveness in past studies (Baldwin and Hughes, 1995; Gales and Blackburn, 1990). Gobeli and Seville's (1989) results show that most small business owners perceive accountants to be helpful only in tax return preparation rather than in management information system design or forming strategic marketing and management plans. Baysinger and Hoskisson's (1990), Ford's (1989) and Shapiro's (1995) research on effectiveness of boards revealed that most CEOs believed inside directors were more helpful than outside directors because of their knowledge of the firm, but no direct linkage between the use of these boards and positive performance was determined. In an empirical study on information sources for small firms, Specht (1987) and Fann and Smelter (1989) both found personal sources to be more effective than impersonal ones. In light of these studies, the present research focuses on different types of personal sources.

\section{Performance}

In their research, Holmes and Nicholls (1988) found a tentative assistance-performance linkage to the use of professional accountants; the "lower the level of sales, the greater the proportion of owner/managers restricting accounting information to ST (statutory - meaning for IRS tax returns)." That is, firms with greater sales volumes used accountants for preparation of tax returns as well as budgets and plans. Dollinger (1985) also found that the use of outside consultants (marketing and management) was positively correlated with performance, measured as perceived organizational effectiveness in 53 small retailing firms.

Probably the strongest empirical evidence supporting the relationship between the use of entrepreneurial assistance and firm performance has been conducted by Chrisman and Leslie (1989). Rather than concentrating on the different forms of outside assistance (such as formal and advisory boards, accountants, family, friends), they studied three types of assistance, namely, "strategic, administrative, and operating" and their impact on performance. Two financial performance criteria were utilized in their research - sales growth and 
incremental return on sales (ROS). The major finding of the paper was that only firms which obtained comprehensive assistance (meaning of all three types) were better performers in terms of ROS. None of the assistance types were significantly linked to sales growth. While this study focuses on the impact of the content of assistance on performance of the firm, it is limited in some important ways - the sample size is fairly small (Watts and Ormsby, 1990); performance was measured narrowly by two financial criteria; and assistance was received through one form (i.e. government sponsored assistance through a SBDC - Small Business Development Center in Georgia). Another study with the similar limitation of having examined only SBDC consulting and performance did confirm the link of advisors to upward trends in sales, profit, net worth, and number of employees (Nahavandi and Chesteen, 1988). Dollinger (1985) like Chrisman et al. (1989) says comprehensive attention to a mix of factors (i.c. suppliers, marketing and management consultants, trade associations, regulators, stockholders and competitors) contributes to higher sales, net income and profitability for small firms.

Building upon this foundation of research, the present study analyzes a varicty of assistance forms in a larger sample size with a more comprehensive look at performance criteria. That is, the goal of this research is to comprehensively evaluate the advisors and their relationship to positive company performance measures found in previous research: sales (Chrisman and Leslie, 1989; Nahavendi et. al, 1988); market share (Gales and Blackburn, 1990); productivity - sales per employee (Garsombke and Garsombke, 1989); return on sales (Cragg and King, 1988; Franklin and Goodwin, 1986); return on assets (Hornaday and Wheatley, 1986); return on equity and new geographical sales area (Garsombke et. al, 1989).

\section{Inhibitors}

Another important area of research on board of directors/management advisory assistance deals with the barriers facing small businesses in the development and use of advisors. If a firm is not using a board of directors or other entreprencurial assistance, are there reasons why? Most of the impediments to assistance researched thus far have concentrated on the cost of establishing or maintaining these boards or advisors and finding appropriate expertise in needed functional areas and the industry. Smale et. al (1995) suggest that small companies have difficulty in providing the resources needed to acquire and develop outside expertise and advisory assistance. In fact, Shapiro cautions small businesses to "leverage their internal brainpower first before calling consultants" (1995, p. 31). Weiss (1995) and McMenamin (1993) researched the inhibitors which affect the entrepreneur's use of outside advisors and state that the factors are primarily lack of financial and organizational resources. While small businesses will surely benefit from long term planning, marketing techniques which include building relationships as well as enhancing sales, preparation of organizational documents, and computer utilization, most of these 
smaller firms encountered significant problems in setting up and fully implementing their consultant's advice.

\section{Methodology}

A mail questionnaire was the basic research methodology used in this study with questions developed into four major topical areas. The first section contained a list of various board of directors/management advisory assistance forms previously evaluated by researchers (Gales and Blackburn, 1990; Nahavandi and Chesteen, 1988; Specht, 1987; Verespej, 1994; Weidenbaum, 1995). The forms of assistance described above included both advisory and governing, individual and group, and professional and non-professional. The "usage" of assistance measured the amount each assistance form was consulted over the past 3 years through a 5 point Likert scale with ' 1 ' being "used very little" and " 5 ' being "used extensively." The "effectiveness" of managerial assistance was measured by using a five point Likert scale ranging from "not effective" to "extremely effective." The points were averaged for all respondent firms to calculate an effectiveness score.

The second section consisted of a list of possible inhibitors derived by the authors and other small business professionals in their research (Johnson and Kuehn, 1987; Miskin and Rose, 1990). This list contains factors which have or are presently inhibiting the development and/or implementation of board of directors/management advisory assistance. The third part of the questionnaire identified performance indicators focusing on the seven performance factors from the literature as outlined previously. Because of the reluctance on the part of small business owners to divulge financial data, this study employed self report qualitative measures of positive organizational performance. This performance rating system was designed, tested and utilized by Dess and Robinson (1984). It has been used in a series of studies where current specific financial data have not been available (Chrisman and Leslie, 1989; Garsombke et. al, 1989; Vance, 1983). The fourth major section of the survey contained questions dealing with business characteristics such as approximate annual sales, number of employees, types of products produced, and ownership forms.

\section{The Sample}

The target population for this study included small and medium sized companies in the State of Maine listed in the 1992 Maine Directory of Small and Medium Sized Firms. This directory contains the listing of all manufacturing firms by SIC Code and County. A random number generator was used to select five hundred questionnaire recipients. Of the five hundred firms sampled, one hundred twenty-six firms participated in the study for a twenty five percent $(25 \%)$ response rate. 
A majority of firms in the study had less than one million dollars in annual sales per year $(68 \%)$, had fewer than fifty employees $(69 \%)$, and were incorporated $(81 \%)$. The sample fits well within the guidelines for small business given by Nappi and Vora (1980); a typical small business has less than $\$ 1$ million in sales, 100 employees and is independently operated. Over sixly-seven different SIC Classifications were represented in the responding firms, with the greatest concentration in the manufacturing and marketing of wooden products $(8.5 \%)$. Products manufactured included wood products, mat tresses and springs, canned foods, packaging material, metal fabrication, electronic parts and equipment, printing, and building materials. Of the firms responding, fifty-nine per cent (59\%) identified themselves as manufacturers, seven per cent $(7 \%)$ as wholesaler/distributor, five per cent $(5 \%)$ as service businesses, and three per cent $(3 \%)$ as retailers and twenty six per cent $(26 \%)$ as a mixed type. Chi-square analysis of response and nonresponse firms showed no significant differences between the two groups regarding product type, number of employees, amount of yearly sales, and type of ownership. Backwards stepwise regression statistics were utilized to enable the researchers to focus on the most elemental factors by taking out those which did not add significantly to the overall effectiveness model.

\section{Results}

Table 1 summarizes the commonly used forms of assistance (frequency and percent of usage) by the responding firms and how effective these forms are relative to one another. The most frequently eited factors which inhibit

Table 1

Usage (Frequency and Per Cent) and Effectiveness of Board of Directors and Management Advisory Assistance Forms

\begin{tabular}{lccc} 
& $\begin{array}{c}\text { Usage } \\
\text { Frequency }\end{array}$ & $\begin{array}{c}\text { Usage } \\
\text { Percent }\end{array}$ & Effectiveness \\
\hline Accountant & 102 & 81 & 3.12 \\
Attorney & 90 & 71 & 3.16 \\
Banker & 72 & 57 & 3.60 \\
Consultant & 70 & 56 & 3.66 \\
Governing Board & 61 & 48 & 3.49 \\
Trade Association & 60 & 47 & 3.50 \\
Friend or Relative & 58 & 46 & 4.14 \\
Supplier & 58 & 46 & 4.64 \\
Advisory Board & 50 & 40 & 3.62 \\
Government Sponsored Program & 47 & 37 & 2.94 \\
(i.e. SBDC. SCORE. SBI. SBA) & & & \\
Customer & 11 & 9 & 1.85
\end{tabular}


implementation of advisors are shown in Table 2. While these statistics show some interesting patterns regarding use and perceived effectiveness of assistance and their inhibitors, they do not address the question of significance. Table 3 addresses this issue and reports the significant regression results relevant to each of the assistance forms and performance factors studied.

Table 2

Frequency and Percent of Inhibiting Factors

\begin{tabular}{lcc} 
Factors & Frequency & Perce \\
\hline Belief advisors would not help & 47 & 37 \\
Lack of time to evaluate & 43 & 34 \\
Lack of capital & 34 & 27 \\
Lack of staff & 32 & 26 \\
Lack of knowledge & 31 & 25 \\
Difficulty of obtaining funds & 20 & 16 \\
Lack of advisors in area & 16 & 13
\end{tabular}

Table 3

Summary Table for Significant Regressions of Performance Factors on Advisory Forms

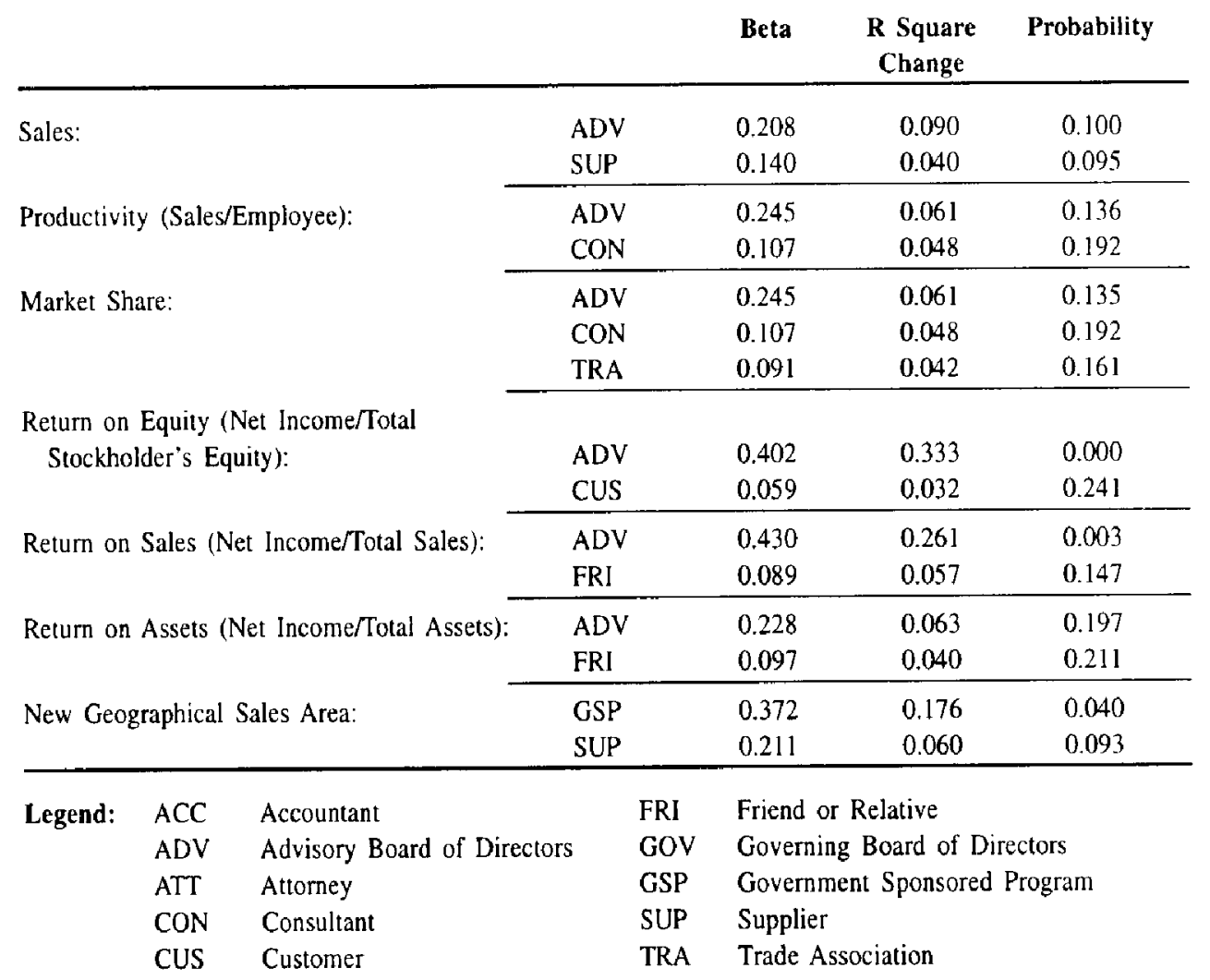




\section{Discussion of Strategic Marketing and Planning Implications}

\section{Advisors}

The first area explored in this study was the advisory form entrepreneurs used and their perceived effectiveness of these forms. Entrepreneurs most often used a board of directors, which is a group form of professionals. This represents an increase in usage of boards by smaller firms since Vance's (1983) study, which reported small business use at approximately $80 \%$. The next most used forms of advisors were individual professionals: accountants (81\%), attorneys $(71 \%)$, bankers $(57 \%)$, and marketing and managerial consultants $(56 \%)$. These results are consistent with previous research findings (Gales and Blackburn, 1990; Specht, 1987).

The "governing" board of directors form was used slightly more frequently (48\%) than the "advisory" board form (40\%). Government programs and customers, as advisory forms, were the least used (37\% and $9 \%$ respectively). Explanations for this low usage of government programs and customers when compared to other forms are related to the perception of the government and customers by small business owners. Small business, in general, is suspect of government interference and bureaucracy; customers are seen as sources of revenues, not assistance to overcome problems the business faces. Many entrepreneurs believe that admitting they have problems and need outside help could hurt customer confidence and loyalty. However, entrepreneurs should be careful not to miss opportunities to gain advice from their customers especially in the areas of new product development and existing product improvements. Most small businesses have become competitive because they have offered something special to their customers or appealed to a unique customer group or niche.

Of the most used forms of advice, small business owners who responded believed that suppliers and friends were the most effective forms of advisory assistance. Consultants, bankers, boards, trade associations, attorneys, and accountants were next in order of perceived effectiveness. Government programs and customers were judged to be the least effective forms. Counterpointing usage and effectiveness brings two strategic implications for entrepreneurs. Although usage is relatively low, assistance from suppliers and friends is perceived as extremely effective. Perhaps this has to do with the fact that small business people did not pay for this assistance and yet the results surpassed their expectations. In addition, of all assistance forms, suppliers and friends seem likely to be viewed as trustworthy and helpful. Such a view builds up with long term relationships of this kind (Weiss, 1995). Also more frequent and intense communications with suppliers have been tied to more frequent use of advertising and strategic marketing plans (Gales and Blackburn, 1990; Franklin and Goodwin, 1986). Entrepreneurs who are not establishing these strong relationships may be overlooking the benefits of such contacts. 
It is important to note that professional assistance, both group and individual, also fared well. Usage and effectiveness were relatively high for these forms. This is contrasted to the forms of government sponsored programs and customers, which had relatively low usage and poor effectiveness ratings. One may wonder, in fact, if low usage of these forms is due to the perceived effectiveness of these sources. Word of mouth between entrepreneurs is often the way the business community hears about sources of assistance. Consultants have long used testimonials of entrepreneurs and clients to increase their business.

\section{Inhibitors}

The most frequently cited inhibitors found in the study were a "belief that management advisory assistance or board of directors would not help operations" (37\%) and "lack of time to investigate management advisory assistance" (34\%). "Lack of capital" was the reason checked for inhibiting use of assistance by $27 \%$ of the respondents. Other research on advisors have reported lack of resources (i.e. time and money) as the major obstacles (Fraser, 1995; Gales and Blackburn, 1990). Examining Watts and Ormsby's (1990) research on the effects of long-range planning on small firm performance, insights can be drawn regarding inhibitors to advisors. Attitude was found to be of paramount importance; $79 \%$ of managers in the lower performing group said that the expense and time involved in planning often outweighed the benefits. It could be that some entrepreneurs do not believe the benefits of advisors outweigh the expense and time involved in soliciting advice. This study addresses the issue of benefit of advisors to the firm by relating assistance forms and performance measures.

\section{Sales}

A backwards stepwise multiple regression analysis was performed to test the relationships between the studied independent variables (usage of each advisory form) and the dependent variables (seven performance factors). Results reveal that the performance factor of sales was positively impacted by two independent variables, "advisory board of directors," and "supplier or resource contributors." These two factors together accounted for $20.6 \%$ in the variance in sales (i.e. usage of an advisory board and supplier for business advice).

This confirms that advisory boards are beneficial to the firm as Castaldi and Wortman (1984) predicted in their research - the "collegial" board structure (also called quasi or advisory board) was deemed as the most "efficient" form and "crucial to success". The finding on suppliers being a good source of advice parallels the research of Dollinger (1985) on environmental contacts and performance - entrepreneurs who repeatedly contacted suppliers for information and advice (primarily to get environmental information for use in strategic marketing and planning) had higher sales and net incomes in their firms. The results did not confirm the finding of a positive relation- ship be- 
tween sales and use of government sponsored programs, particularly SBDC, which Nahavandi and Chesteen (1988) reported. However, it could be interpreted that the advisory board and suppliers did give the same type of information that SBDC consultants were most often reported giving - business planning (17\%) and marketing planning (19\%).

The present study did not collaborate Holmes and Nicholls's (1988) linkage between use of accountants for planning and sales increases. The finding on the importance of suppliers and advisors confirms somewhat the recent empirical work by Gales and Blackburn (1990) that showed close wholesale relationships (greater communications) impacted retailer planning and promotional activity although not sales or profitability directly. Together with previous research, the current study suggests that suppliers can provide information and advice to significantly benefit their small firm clients.

Only two independent variables, "advisory boards" and "consultants," accounted for eleven percent $(11 \%)$ of the variance on productivity, which was measured as the ratio of sales per employee. Again, this result corresponds to the belief (Castaldi and Wortman, 1984, 2) that the "collegial" board structure was the most "efficient" form, which could easily relate to greater productivity. Although no study on advisors which assessed productivity can be found to compare to these results, Nahavandi and Chesteen's (1988) research looked at sales and number of employees as separate factors relating to SBDC consulting. From an analysis of these separate results, productivity was also positively impacted because sales increased more percentage points $(35 \%)$ relative to the percentage increase in the number of employees (19\%).

In the present study, entrepreneurs were asked to evaluate the effectiveness of paid professional consultants to free SBDC student consultants (in the form of "government sponsored programs") and the professional emerged as more effective. So it is not really surprising that the professional consultant would have a more significant relationship to small firm performance. Nahavandi and Chesteen (1988) themselves questioned the owner/managers why they did not implement the student consultant recommendations and two areas emerged - the lack of the consultants' experience and their understanding of the business, particularly in overall business and marketing planning.

\section{Market Share}

Three variables were moderately related to the market share factor - "advisory boards," "consultants" and "trade association assistance" with 15\% of the changes in market share being explained by these variables. The impact of all three advisors was fairly evenly split, but advisory boards showed a larger beta weight. Market share is an illusive goal since it is very hard to define markets. It is noteworthy that this factor should have a variety of assistance forms which are related, but yet only explain a relatively small amount of the flux in market share. As evidenced from previous studies on market share, a complex array of factors such as advertising expenditures, industry 
stage, competitive factors, the degree of marketing research and planning and other market-related factors have been found to be significant (Baldwin and Hughes, 1995; Provan and Skinner, 1989; Specht, 1987).

\section{Profitability Ratios}

The analysis also revealed that 2 independent variables accounted for 36 percent of the positive variation in return on equity. "Advisory boards" usage was highly significant contributing over $33 \%$ of the variance in ROE and "customer" assistance explained 3\% of the changes in this performance factor. In his study, Dollinger (1985) used a slightly different measure of profitability (i.e. the owner's draw, fringe benefits, cash dividends and net income divided by the prorated percentage of ownership) and uncovered a negative relationship with the customer. He explains this unexpected outcome between a high number of customer contacts and low profitability by saying the entrepreneur is taking on the role of sales personnel and does not have time for other executive tasks which are more cost efficient and profit generating activities. When the customer contact is factored out of Dollinger's correlation, the remaining factors together (including trade associations, suppliers and consultants but no categories for government sponsored programs or boards) accounted for $36 \%$ of the variance in profitability.

The strongest positive relationship was found between the dependent variable of return on sales and the independent variable of "advisory board" assistance. This assistance form accounted for over $26 \%$ of the variance in ROS and was weighted the highest of all dependent variables studied (beta of 0.430 ). In addition, the variable of "government sponsored programs" was moderately related to this variable measuring profit margin. Interestingly enough, these two advisor forms are usually without significant cost to the firm in terms of money, but may be high in terms of time. ROS is positively effected by strategies and advice that result in lowering costs and/or increasing gross revenues. This result confirms two previous studies: Nahavandi and Chesteen (1988) reported a $23 \%$ average increase in profit margin for firms using SBDC consulting in the state of Utah; Chrisman and Leslie (1989) analyzed that comprehensive advice on strategic, administrative and operating decisions by SBDC consultants resulted in significant ROS increments.

The regression equation for return on assets showed only marginally significant and weak relationships with "advisory board" and "friends" in the expected positive direction. Possible explanations for this could be that assets increased relative to net income for the sampled firms on a whole and thus advisor choice did not serve as a discriminating factor. In fact, for manufacturing firms in Maine inefficient asset acquisition could be triggered by the recent economic slowdown and competitive pressures to keep up with technological advancements. 


\section{New Geographical Sales Area}

Two variables (government sponsored programs and suppliers) were strongly related to an increase in new geographical sales area, explaining twenty-four percent of the variance. Manufacturing firms which experienced greater growth in their geographical sales area (i.e. going from a local to regional to national or international area) used suppliers and government sponsored consultants as advisors. These two forms of advisors could offer clients their knowledge about the state, regional, national and/or international sales areas and markets that the small firm may not have or be able to acquire on their own. For example, the federal government through its SBA programs offers export seminars and resources to small firms. In the state of Maine, particular emphasis on expanding to international sales areas has been given in seminars on Canadian markets and the recent Free Trade Agreement. Experts agree that suppliers have valuable information on sales regions in which they hope to expand because of a competitive edge or where they have recently lost a distributor, client or competitor. Often they entice small firms to enter new territories to fill these gaps by offering them purchasing discounts and exclusive contracts. Suppliers also offer information concerning products, markets, competitors, and the general business environment which could easily contribute to expansion into new geographical areas as well (Dollinger, 1985; Franklin and Goodwin, 1986; Provan and Skinner, 1989).

\section{Conclusions}

\section{Advisory Boards}

From the data analyzed, most of the performance factors were positively related to the use of an advisory board of directors. Although this form of management advisory assistance appeared to have the greatest overall impact on performance, it was utilized by only $40 \%$ of the businesses, ranking eighth out of the eleven forms of assistance. Advisory boards had the greatest impact on the profitability ratios of return on equity and sales, in rank order. The use of boards by entrepreneurs seems to be increasing in popularity, as evidenced by the $88 \%$ of the sample who had one. Boards offer the entrepreneur contact with a group of professionals with a variety of backgrounds - marketing, accounting, legal, managerial, and financial - and therefore the content of advice is probably more comprehensive than most of the individual advisors (Park, 1995). This study leads credence to the idea that the comprehensiveness of advice leads to better performance, but did not fully support that advice from many sources at once is better than from one source, as in Dollinger's (1985) work. Although some evidence for the cumulative effect of different advisory groups was given (eg. government sponsored programs contributed $18 \%$ to expansion in geographical areas by itself, but taken together with the impact of suppliers explained $24 \%$ of the difference in this 
performance variable). Clearly, however, for overall impact on performance, seeking assistance from an advisory board was the most beneficial choice.

So why did the advisory board seem to overshadow the governing board in these results? This intriguing question may be answered by the purpose of the advisory board - which is to advise or counsel - as compared to the governing board - which is to govern or control the actions of the entrepreneur. The difference is in the setup and charter given them. When the board is given legal responsibility and structural power, the entrepreneur is in fact sharing some of the decision making role. Although small privately-owned firms are under no obligation to have a board, beyond the minimally required state specified constitutional board, many entrepreneurs have created fully functioning boards, some advisory and some governing. Inherently, there is more resistance to the governing form and more voluntarism in the advisory form (Verespej, 1994).

The advisory board can be an easy way for an entrepreneur to get professional consulting advice. For example, when John Fox was starting up Minute Maid in 1945, he said that he used the board as a "substitute, and a really cheap substitute, for all the consultants I couldn't afford. They helped me decide on such vital issues as getting the company launched . . . held my hand through all kinds of growing pains" (Vance, 1983, 25).

In an advisory form, directors offer their general or specialized backgrounds and experiences to be applied to specific marketing, financial and management problems of the company (Baldwin and Hughes, 1995; Fraser, 1995). In fact, successful entrepreneurs select directors on their complementary knowledge and specialties to best fit the needs of the firm and management, but contrary to popular belief that does not always mean that the majority of board members are outsiders. In fact, Ford (1988) showed that the predominantly insider (members of family, and present, former, or retired managers or officers of the firm) boards are more influential.

\section{Contingency Theory}

From the research, it is evident that small business decision makers need to select assistance forms with the most impact on the performance criteria which are important to them. For example, if sales or return on sales are extremely important, the advice of an "advisory board" should be sought. If growth into new geographical areas is the target, "government sponsored programs" and "suppliers" together would be the best choice for assistance. But, performance goals are sometimes contradictory. For example, Hornaday and Wheatley (1986) showed that organizational growth was not correlated with higher profits in small retail firms. The strategic implications of this research are that there are tradeoffs between performance measures which affect the impact of the various forms of managerial assistance. Entrepreneurs should decide on their primary emphasis and choose advisors to fit those strategic goals. In addition, advisors are only one factor among many which can help 
to attain strategic goals and entrepreneurs need to utilize other key success factors to accomplish their strategies and objectives.

This study is an initial attempt to determine the impact that usage of advisors have on positive performance of small businesses. While entrepreneurs overwhelmingly (94\%) use some advisory form to help in running their firms, the form of "advisory board of directors" appears to have a greater impact on positive performance than other forms of advisors, even though advisory boards were utilized less frequently than other forms such as accountants, attorneys, and bankers - which were utilized the most. After the advisory board, government sponsored programs and suppliers showed the next greatest potential for specific performance improvements in small firms.

\section{Future Research}

Future research could be attempted to determine more specifically the type or content of advice and information (functional knowledge such as marketing or financial or kind of information such as strategic versus operational) for each advisory form. This could clarify why the individual professional advisors such as attorneys, bankers, accountants, and lawyers, although perceived as being effective, did not show any empirically significant relationships to performance. It seems likely that these types of professionals give a narrow array of advice and information that is related to their specialty, but further research is warranted to test this assumption. This study shows that the choice of advisory forms depends both on the needs of the entrepreneur and the performance goals sought, and adds to existing contingency theory.

Future research could expand the performance model to include factors along with advisors such as innovativeness, owner decision making, and goal setting, which Dollinger (1985) found related to performance. In addition, future research could focus on firm and industry differences as well. Due to the limitation of a single state sample, it's recommended that future studies expand this research drawing a sample from several other states or nationally to increase the meaningfulness and generalizability of the results.

This study has shown that the greatest inhibitor to small business use of boards and advisors was the belief that these forms of advisors would not help operations and provide the company with viable assistance. Additionally, the results confirm previous research which cited lack of time and resources as major inhibitors to use of advisors. This and future research analyzing the role of advisors more fully could contribute to eliminating the bias against use of advisors and convince entrepreneurs that the time and resources expended in gaining advice would be beneficial to the success of the firm. 


\section{References}

Baldwin, Rollin P. and Jonathan T. Hughes. Boards at Their Best: A New Approach Toward Improved Board Effectiveness. New York: Connolly-Cormack, 1995.

Baysinger, Barry and Robert E. Hoskisson. "The Composition of Boards of Directors and Strategic Control: Effects on Corporate Strategy." Academy of Management Review 15(1), (1990): 72-87.

Business Owner. "How to Use Outside Advisers to Maximize Corporate Results." Business Owner $9(6),(1985): 13-14$.

Castaldi, Richard, and Max S. Wortman. "Boards of Directors in Small Corporations: An Untapped Resource." American Joumal of Small Business 9(2), (1984): 1-9.

Chrisman, James J. and John Leslie. "Strategic, Administrative, and Operating Problems: The Impact of Outsiders on Small Firm Performance." Entrepreneurship Theory and Practice 13(3), (1989): 37-51.

Cragg, Paul B. and Malcolm King. "Organizational Characteristics and Small Firms' Performance Revisited." Entrepreneurship Theory and Practice 13 (Winter, 1988): 49-64.

Dess, G. G. and Richard B. Robinson. "Measuring Organizational Performance in the Absence of Objective Measures: The Case of the Privately Held Firm and Conglomerate Business Unit." Strategic Management Journal 5 (1984): 265-273.

Dimma, William A. "The Changing Role of the Board of Directors." Vital Speeches of the Day 62 (January 15, 1996): 217-220.

Dollinger, M. J. "Environmental Contacts and Financial Performance of the Small Firm." Journal of Small Business Management 23 (January, 1985): 24-30.

Fann, G. and L. R. Smeltzer. "The Use of Information From and About Competitors in Small Business Management." Entrepreneurship Theory and Practice 13 (Summer, 1989): $35-46$.

Ford, Roger H. "Outside Directors and the Privately-owned Firm: Are They Necessary?" Entrepreneurhip Theory and Practice 13(1), (1988): 49-57.

Fox, Harold W. "Quasi-boards: Guidance without Governance." American Journal of Small Business 9(1), (1984): 12-18.

Franklin, Stephen G. and Jack S. Goodwin. "Problems of Small Business and Sources of Assistance: A Survey." Journal of Small Business Management 2(2), (1986): 5-12.

Fraser, Jill A. "Boardroom Benefits." Inc 17 (August, 1995): 103-104. 
Gales, L. and R. S. Blackburn. "An Analysis of the Impact of Supplier Strategies and Relationships on Small Retailer Actions, Perceptions, and Performance." Entrepreneurship Theory and Practice 15 (Fall, 1990): 7-22.

Garsombke, Diane J. and Thomas W. Garsombke. "Robots, Computers, and Automation: Implications for Small Manufacturers." Journal of Small Business Management 27(4), (1989): 34-44.

Gobeli, David H. and Mary Alice Seville. "The Small Business-CPA Interface." Journal of Small Business Management 27(4), (1989): 8-16.

Holmes, Scott and Des Nicholls. "An Analysis of the Use of Accounting Information by Australian Small Business." Journal of Small Business Management 26(2), (1988): 57-68.

Hornaday, R. W. and W. J. Wheatley. "Managerial Characteristics and the Financial Performance of Small Business." Journal of Small Business Management (April, 1986): $1-7$.

Ibrahim, A. B. and J. R. Goodwin. "Perceived Causes of Success in Small Business." American Journal of Small Business 11(2), (1986): 41-50.

Johnson, L. and L. Kuehn. "The Small Business Owner/Manager's Search for External Information." Journal of Small Business Management (July, 1987): 53-60.

Kesner, Idalene F. "Directors' Characteristics and Committee Membership: An Investigation of Type, Occupation, Tenure, and Gender." Academy of Management Journal 31(1), (1989): 66-84.

Khan, M. R. and J. R. Rocha. "Recurring Managerial Problems in Small Business." American Journal of Small Business 7(1), (1982): 50-58.

Lorsch, Jay W. "Empowering the Board." Harvard Business Review 73 (Jan-Feb, 1995): 107-110.

McMenamin, Brigid. "Non-Executive Stress: The Quality of Outside Directors in Company Boardrooms." The Economist 329 (November 6, 1993): 15-17.

Miskin, Val and Jerman Rose. "New Venture Initiation: Factors Influencing Success." Journal of Small Business Strategy 1 (October, 1990): 1-9.

Montagno, R. V., D. F. Kurato, and J. H. Scarcella. "Perception of Entrepreneurial Success Characteristics." American Journal of Small Business 10(3), (1986): 25-32.

Nahavandi, Afsaneh and Susan Chesteen. "The Impact of Consulting on Small Business: A Further Examination." Entrepreneurship Theory and Practice 13 (Fall, 1988): $29-40$. 
Nappi, A. R and Jay Vora. "Small Business Eligibility: A Definitional Issue." Journal of Small Business Management (October, 1980): 23.

Nelson, George W. "Factors of Friendship: Relevance of Significant Others to Female Business Owners." Entrepreneurship Theory and Practice 13(4), (1989): 7-18.

Park, Jae C. "Reengineering Boards of Directors." Business Horizons 38 (March-April, 1995): 63-74.

Provan, K. G. and Skinner, S. J. "Interorganizational Dependence and Control as Predictors of Opportunism in Dealer-Supplier Relations." Academy of Management Journal 32 (1989): 202-212.

Shapiro, Eileen. "Consultant Trap." Inc 17 (December, 1995): 31-32.

Smale, John G., Alan Patricof, Denys Henderson, Bernard Marcus, and David W. Johnson. "Redraw the Line : Between the Board and the CEO." Harvard Business Review 73 (March, 1995): 153-165.

Specht, P. H. "Planning Group Characteristics as Moderators of the Relationship Between Perceived Environmental Characteristics and Information Sources Used." American Journal of Small Business 4 (1987): 21-34.

Vance, Stanley C. Corporate Leadership: Boards, Directors, and Strategy. New York: McGraw-Hill, Inc., 1983.

Verespej, Michael A. "What's Next for Directors?" Industry Week 243 (February 21, 1994): 11-13.

Watts, Larry and J. G. Ormsby. "The Effect of Operational and Strategic Planning on Small Firm Performance." Joumal of Small Business Strategy 1(2), (October, 1990): 27-35.

Weidenbaum, Murray L. "The Evolving Corporate Board." Society 32 (March-April, 1995): $21-24$.

Weiss, Alan. "Double Your Fees: 8 Ways to Grow a Successful Consulting Business." Home Office Computing 13 (September, 1995): 54-58.

Diane J. Garsombke, (Ph.D., University of Tennessee), is Associate Professor of Management and Chairperson of the Department of Business Administration, University of Wisconsin Superior. Her research concentrates on strategic management of small businesses in America and Asia. Her publications include the International Management Review, Journal of Small Business Management, Planning Review and Organizational Dynamics. She has taught and consulted in Russia, Indonesia, Malaysia, and Belize. 
Vol. 13, No. 2

Thomas W. Garsombke is Visiting Professor of Business Administration at the University of Minnesota Crookston. His research has been published in the Journal of Small Business Management, Business Insights, Issues in International Business and the Journal of Marketing. He has taught in Executive M.B.A. Programs in Hong Kong, Malaysia, and Singapore. Additionally, he has worked with Guatemalan entrepreneurs and consulted under the Asian Development Bank in Indonesia. 